\title{
KINERJA PRODUKTIVITAS DAN FAKTOR YANG BERPENGARUH TERHADAP TOTAL FACTOR PRODUCTIVITY (TFP )TAMBAK UDANG INDONESIA ${ }^{1}$
}

\author{
Ono Juarno ${ }^{2}$, Rina Oktaviani ${ }^{3}$, Akhmad Fauzi ${ }^{4}$ dan Nunung Nuryartono ${ }^{5}$ \\ ${ }^{1}$ Merupakan bagian dari disertasi Sekolah Pasca Sarjana, IPB; \\ ${ }^{2}$ Mahasiswa S3 Program Studi IImu Ekonomi Pertanian, Sekolah Pascasarjana, IPB; \\ ${ }^{3}$ Ketua Komisi Pembimbing \\ 4 dan 5 Anggota Komisi Pembimbing \\ Diterima 26 Agustus 2011 - Disetujui 14 Oktober 2011
}

\begin{abstract}
ABSTRAK
Kuantitas produksi udang tambak Indonesia meningkat signifikan dalam dua dekade terakhir, dari 97,2 ribu ton tahun 1989 menjadi 352 ribu ton tahun 2010, dengan puncaknya 409 ribu ton pada tahun 2008. Studi ini bertujuan untuk menganalisis kinerja produktivitas tambak udang dan mengetahui faktor-faktor yang mempengaruhi TFP menggunakan pendekatan angka Indeks Tornqvist Theil. Hasil studi menunjukkan bahwa pertumbuhan udang tambak Indonesia periode 1989-2008 lebih karena pertumbuhan input/faktor produksi bukan karena pertumbuhan TFP. TFP berfluktuasi disebabkan belum berhasil diatasinya permasalahan penyakit. Hasil konfirmasi pada tingkat lapang menggunakan data primer dari 163 petak tambak menunjukkan bahwa serangan penyakit berpengaruh negatif dan signifikan terhadap TFP. Intensifikasi, benur bersertifkat, dan lamanya pendidikan berkorelasi positif, akan tetapi kondisi riil Indonesia berbeda yaitu mayoritas tambak dikelola secara non intensif. Studi ini juga menunjukkan bahwa luas pengusahaan dan sistem kerjasama antara pembudidaya dengan lembaga pemasaran lainnya berpengaruh negatif terhadap TFP. Terkait dengan hal itu, pemerintah perlu memprioritaskan meningkatkan produktivitas dengan mengatasi serangan penyakit melalui penambahan anggaran riset bidang penyakit, penyediaan benur bermutu, peningkatan sumber daya manusia (SDM). Selain itu, diperlukan regulasi dalam hal pengaturan pola tanam dengan penggantian species yang dapat memutus rantai penyakit. Disamping itu, direkomendasikan agar mengurangi padat penebaran.
\end{abstract}

Kata Kunci: : produktivitas, TFP, Udang tambak, Indonesia

\section{Abstract : Productivity Performance and Factors Influencing to the Total Factor Productivity (TFP) of Indonesia Shrimp Cultured. By: Ono Juarno, Rina Oktaviani, Akhmad Fauzi and Nunung Nuryartono.}

Production of Indonesian shrimp cultured has experienced a tremendeous growth during the last two decades with its peak performance at 409 metric tons in the year of 2008. The objective of this research was to analyze productivity performance of Indonesian shrimp cultured using the Tornqvist Theil Index and its determinants. Results showed that source of growth was mainly due to input gowth. TFP fluctuations were mainly because of disease outbreaks. Using field data comprises a total of 163 ponds confirm that disease outbreaks plays an important role in lowering TFP. Intensification, fry certification, and education halved a positive correlation with TFP. However, the Indonesian shrimp farmers in majority cultured the shrimps using traditional system. On the other hand, cooperation between farmers and other marketing institution and total pond area show a negative effects on achieving higher TFP. Therefore, the government could improve farmed shrimp productivity through increasing research budget on diseases, improving seed quality and human resources. The government should also put a priority regulation on changing cropping system accompanied by changing shrimp species cultured so that carrier agents of diseases can be broken. Apart from these, lowering stocking density was also suggested.

Keyword : productivity, TFP, shrimp cultured, Indonesia 


\section{PENDAHULUAN}

Produktivitas merupakan salah satu faktor penting penentu pertumbuhan ekonomi. Menurut Asche et al. (2007), produktivitas merupakan sumber pertumbuhan pada komoditas perikanan yang produksinya meningkat signifikan seperti ikan Salmon. Demikian halnya dengan udang, kuantitas produksi udang hasil budidaya di dunia meningkat signifikan dari 0.17 juta ton pada tahun 1984 menjadi 3.20 juta ton tahun 2008. Akibatnya, proporsi udang hasil budidaya terhadap total produksi udang dunia meningkat dari 9.2\% pada tahun 1984 menjadi $43.0 \%$ pada tahun 2008. Peningkatan tersebut disebabkan kemajuan dibidang pakan, manajemen tambak, dan pembenihan berupa introduksi udang vaname (Litopenaeus vannamei) ke negara-negara di Asia pada tahun 2000. Udang vaname memiliki produktivitas sekitar tiga kali lebih tinggi dibandingkan dengan produktivitas udang windu (Penaeus monodon) (Wyban, 2007).

Di Indonesia, kuantitas produksi udang hasil budidaya juga meningkat nyata dalam 20 tahun terakhir, dari hanya 97.2 ribu ton pada tahun 1989 menjadi 352.0 ribu ton pada tahun 2010. Puncaknya terjadi pada tahun 2008 dengan kuantitas produksi sebanyak 409.6 ribu ton. Akan tetapi, dengan luas tambak 350 ribu $\mathrm{Ha}$, capaian tersebut masih jauh dibandingkan Thailand yang hanya memiliki luas tambak sekitar 64 ribu $\mathrm{Ha}$. Thailand mampu memproduksi udang sekitar 500 ribu ton per tahun pada periode 2007-2010 dan bahkan pada tahun 2009, Asosiasi Pembudidaya Thailand berencana mengurangi produksi dalam rangka menjaga penurunan harga (The Nation, 2009), walaupun pada akhirnya, rencana tersebut batal karena udang tambak di negara eksportir lain termasuk Indonesia terkena serangan penyakit.

Studi ini menganalisis kinerja produktivitas dalam peningkatan kuantitas produksi udang tambak Indonesia, dan menganalis faktor-faktor yang mempengaruhinya.
Studi kebijakan sebelumnya seperti International Finance Corporation (IFC) (2006, 2007), USAID (2006), dan World Bank (2006) berturut-turut untuk Indonesia, Nigeria, Bangladesh, dan Pakistan, menunjukkan pentingnya peningkatan produktivitas dan mutu agar udang dari negara-negara tersebut mampu bersaing di pasar internasional. Hasil studi ini diharapkan berguna sebagai bahan informasi dan pertimbangan menyusun kebijakan produksi udang tambak Indonesia.

\section{METODOLOGI}

\section{Lokasi dan Waktu Penelitian}

Produktivitas tambak udang kurun waktu 1989-2008 dianalisis pada tingkat nasional, dan hasilnya dikonfirmasi pada tingkat lapang. Pada tingkat lapang, lokasi dipilih secara sengaja (purposive) yaitu tambak di Provinsi Jawa Timur, dan dibandingkan dengan tambak di luar Provinsi Jawa Timur (Provinsi Lampung, Sulawesi Selatan, NTB, dan Jawa Barat). Provinsi Jawa Timur dipilih karena mempunyai sistem usaha budidayanya lengkap mulai dari ekstensif (termasuk sistem organik), semi intensif, dan intensif. Jawa Timur juga memiliki aktivitas perikanan yang lengkap sejak produksi sampai dengan pemasaran. Provinsi Lampung merupakan menyumbang terbesar produksi udang di Indonesia karena keberadaan perusahaan terintegrasi di bawah CP Prima Grup (PT. Wahyuni Mandira, PT Aruna Wijaya Sakti, dan PT. Central Pertiwi Bahari). Tambak di Provinsi Sulsel mayoritas dikelola secara semi intensif dan ekstensif, sedangkan NTB merupakan daerah pengembangan tambak dan Jawa Barat merupakan daerah yang pernah mengalami kejayaan pada usaha budidaya udang tahun 1990-an. Secara kumulatif, kuantitas produksi udang dari Jawa Timur, Lampung, dan Sulsel mencapai sekitar $70 \%$ dari total produksi udang tambak Indonesia. Waktu pengumpulan data dilaksanakan pada Desember 2009 sampai dengan Maret 2010. 


\section{Data dan Sumber Data}

Analisis produktivitas tambak udang pada tingkat nasional menggunakan data sekunder yang berasal dari Statistik Perikanan Budidaya (Ditjen Perikanan Budidaya, KKP), Survey Perusahaan Perikanan (BPS), dan Statistik Harga Perdagangan Besar Beberapa Provinsi di Indonesia (BPS). Salah satu kelemahan dari data sekunder di negara berkembang, seperti Indonesia, adalah kualitas data. Hal itu juga yang menjadi keterbatasan analisis pada tingkat nasional dari studi ini. Konfirmasi pada tingkat lapang menggunakan data primer berasal dari responden di daerah lokasi penelitian. Data mencakup kuantitas dan harga baik untuk input (faktor produksi) maupun output pada usaha budidaya udang. Informasi ditanyakan dan dielaborasi melalui wawancara langsung menggunakan kuesioner terstruktur. Beberapa simplifikasi dilakukan pada studi ini sehingga hasilnya mungkin bias ke atas maupun ke bawah. Hasil produksi tambak mencakup udang windu, udang putih, udang vaname, udang api-api dan ikan bandeng, disederhanakan menjadi udang windu, udang putih, dan bandeng. Obat-obatan juga beragam terkait pencegahan seperti kapur, dolomit, probiotik, pupuk dan terkait pemberantasan hama seperti pestisida. Pada studi ini obat-obatan yang digunakan setara kapur. Listrik sebagian menggunakan BBM dan sebagian berasal dari PLN menjadi setara pemakaian listrik dari PLN. Dummy kerjasama juga disimplikasi berupa pembudidaya yang melakukan kerja sama dalam arti luas yaitu baik dengan pedagang pengumpul, perusahaan obat, pakan, atau menjadi bagian dari perusahaan terintegrasi.

Teknik penarikan sampel menggunakan metode snowbolling dengan sampling frame berasal dari daftar pembudidaya yang menerapkan Cara Budidaya Ikan yang Baik (CBIB) dari Direktorat Jendral Perikanan Budidaya. Responden berikutnya diambil dari rekomendasi responden sebelumnya. Akhirnya diperoleh 163 petak yang dimiliki oleh 99 pembudidaya, dengan komposisi: 74 petak tambak di Jawa Timur atau 45.4\%, dan 89 petak di luar Jawa Timur atau 54.6\%. Berdasarkan tingkat teknologi, komposisinya intensif sebanyak 98 petak atau $60.12 \%$, dan sisanya 65 petak atau $39.88 \%$ berupa tambak non intensif. Sebanyak 43 petak atau $26.3 \%$ membudidayakan udang windu dan 120 petak atau $73.7 \%$ memelihara udang vaname.

\section{Metode Analisis}

Pengukuran produktivitas, awalnya dilakukan secara parsial, namun konsep ini mempunyai kelemahan yaitu tidak mengukur kontribusi produktivitas seluruh faktor produksi yang terlibat dalam satu proses produksi. Kelemahan tersebut diatasi jika menggunakan pendekatan TFP yang telah memperhitungkan berbagai input yang saling berinteraksi. Menurut Martinez-Cordero et al. (1999) TFP merupakan ukuran kemampuan seluruh jenis faktor produksi sebagai satu kesatuan faktor produksi agregat dalam menghasilkan output keseluruhan. Otsuka (1988) dalam Maulana (2004) mendefinisikan TFP sebagai rasio indeks hasil produksi dengan indeks total faktor produksi.

Terdapat dua metode penghitungan TFP yaitu growth accounting dan pendugaan parametrik atau ekonometrika. Growth accounting menggunakan asumsi Constant Return to Scale, penggunaannya lebih praktis, akan tetapi tidak dapat menghitung efisiensi harga, elastisitas permintaan input maupun penawaran. Keterbatasan tersebut dapat diatasi apabila menggunakan pendekatan ekonometrika.

Pada studi ini digunakan pendekatan growth accounting berupa Angka Indeks Tornqvist-Theil. Angka Indeks TornqvistTheil tersebut telah meminimalisir pengaruh perubahan harga (Fuglie, 2004). Deny dan Fuse (1983) dalam Martinez-Cordero et al. (1999) mengembangkan metodologi penentuan angka indeks intertemporal (antar waktu) dan interspatial (antar tempat). Konsep produktivitas antar waktu sering digunakan untuk melihat perubahan teknis dalam penggunaan faktor produksi dan 
teknologi. Hasil penghitungan TFP akan sama untuk fungsi produksi translog. Pada studi ini, penghitungan perubahan TFP antar waktu untuk periode tahun 19892008 menggunakan indeks Tornqvist-Theil sesuai Caves et al, (1982) dalam Maulana (2004) sebagai berikut:

Penghitungan indeks output:

Penghitungan indeks output:

$$
\ln \left(Q_{t} / Q_{t-1}\right)=0,5 \sum_{j}\left(S_{j}+S_{j-1}\right) \ln \left(Q_{j} / Q_{j-1}\right)
$$

cara yang sama dilakukan untuk menghitung indeks input.

$$
\begin{aligned}
& \ln \left(X_{t} / X_{t-1}\right)=0,5 \sum_{i}\left(S_{t}+S_{t-1}\right) \ln \left(X_{t} / X_{i-1} \ldots\right. \text { (2) } \\
& \ln \left(T F P_{i} / T F P_{t-1}\right)=\ln \left(Q_{i} / Q_{t-1}\right)-\ln \left(X_{i} / X_{t-1}\right) \ldots \text { (3) } \\
& \text { dimana : } \\
& \mathrm{Q}_{\mathrm{t}} \quad=\quad \text { Kuantitas output tahun } \mathrm{t} \\
& \mathrm{Qj}_{\mathrm{t}} \quad=\text { Kuantitasoutput } \mathrm{j} \text { tahun } \mathrm{t} \text {; } \\
& \mathrm{Xi}_{\mathrm{t}} \quad=\quad \text { Kuantitas input } \mathrm{i} \text { tahun } \mathrm{t} \text {; } \\
& \mathrm{Sj}_{\mathrm{t}} \quad=\text { Pangsa dari output } \mathrm{j} \text { tahun } \mathrm{t} \text {; } \\
& \mathrm{Si}_{\mathrm{t}} \quad=\text { Pangsa dari input } \mathrm{i} \text { tahun } \mathrm{t} \text {; } \\
& \text { TFP }_{\mathrm{t}}=\text { Faktor produktivitas total } \\
& \text { tahun t; } \\
& \mathrm{Q}_{\mathrm{t}-1}=\text { Kuantitas output tahun } \mathrm{t}-1 \\
& \mathrm{Qj}_{\mathrm{t}-1}=\text { Kuantitas output } \mathrm{j} \text { tahun } \mathrm{t}-1 \text {; } \\
& \mathrm{Xi}_{\mathrm{t}-1}=\text { Kuantitas input } \mathrm{i} \text { tahun } \mathrm{t}-1 \text {; } \\
& \mathrm{Sj}_{\mathrm{t}-1}=\text { Pangsa dari output } \mathrm{j} \text { tahun } \\
& \text { t-1 ; } \\
& \mathrm{Si}_{\mathrm{t}-1}=\text { Pangsa dari input } \mathrm{i} \text { tahun } \mathrm{t}-1 \text {; } \\
& \mathrm{TFP}_{\mathrm{t}-1}=\text { Faktor produktivitas total } \\
& \text { tahun } \mathrm{t}-1 \text {; }
\end{aligned}
$$

\begin{tabular}{|c|c|c|}
\hline Tliavg & $=$ & TFP tiap petak \\
\hline$Q_{m i}$ & 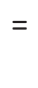 & $\begin{array}{l}\text { kuantitas output dari } \\
\text { species } \mathrm{m} \text { dari tambak i }\end{array}$ \\
\hline$Q_{\text {mavg }}$ & $=$ & $\begin{array}{l}\text { Rata-rata kuantitas output } \\
\text { dari species m untuk selu- } \\
\text { ruh tambak yang diuji }\end{array}$ \\
\hline$S_{m i}$ & $=$ & $\begin{array}{l}\text { Proporsi pendapatan } \\
\text { terhadap tota pendapatan } \\
\text { dari tambak i }\end{array}$ \\
\hline s mavg & $=$ & $\begin{array}{l}\text { Rata-rata proporsi penda- } \\
\text { patan dari seluruh tambak }\end{array}$ \\
\hline$S_{k i}$ & $=$ & $\begin{array}{l}\text { Proporsi input } \mathrm{k} \text { terha- } \\
\text { dap seluruh pengeluaran } \\
\text { tambak } \mathrm{i}\end{array}$ \\
\hline s kavg & $=$ & $\begin{array}{l}\text { Rata-rata proporsi input } k \\
\text { terhadap seluruh penge- } \\
\text { luaran tambak }\end{array}$ \\
\hline$x_{k i}$ & $=$ & $\begin{array}{l}\text { kuantitas penggunaa } \\
\text { input k dari tambak i }\end{array}$ \\
\hline
\end{tabular}

Penghitungan TFP di atas akan memberikan hasil yang tidak konsisten untuk perbandingan multilateral karena permasalahan transitivitas. Untuk itu, penghitungan angka indeks TFP Tornqvist antar wilayah untuk konfirmasi pada tingkat lapang dihitung tersendiri, seperti dilakukan oleh Capalbo dan Antle (1986) dalam Martinez-Cordero et al. (1999) sebagai berikut:

$\mathrm{Tl}_{\text {iavg }}=1 / 2 \sum \mathrm{m}\left(\log \mathrm{Q}_{\mathrm{mi}}-\log \mathrm{Q}_{\mathrm{mavg}}\right)$ $\left(s_{m i}+s_{m a v g}\right)-1 / 2 \sum k\left(s_{k i}+s_{k a v g}\right)\left(\log X_{k i}{ }^{-}\right.$ $\log X_{\text {kavg) }}$

dimana :

Setelah angka indeks TFP tiap petak diketahui, hasilnya kemudian diregresikan untuk menganalisis faktor-faktor yang mempengaruhi TFP. Faktor-faktor tersebut antara lain penggunaan benur bersertifikat, sistem usaha budidaya (dummy intensif dan non intensif), pengaruh lokasi geografis (tambak udang di Provinsi Jawa Timur dan di luar Jawa Timur), luas area, serangan penyakit, tingkat pendidikan, dan aspek kelembagaan (pembudidaya yang melakukan kerja sama baik dengan pedagang pengumpul, perusahaan obat, penyedia pakan, atau menjadi bagian dari perusahaan terintegrasi). Model yang digunakan yaitu: 


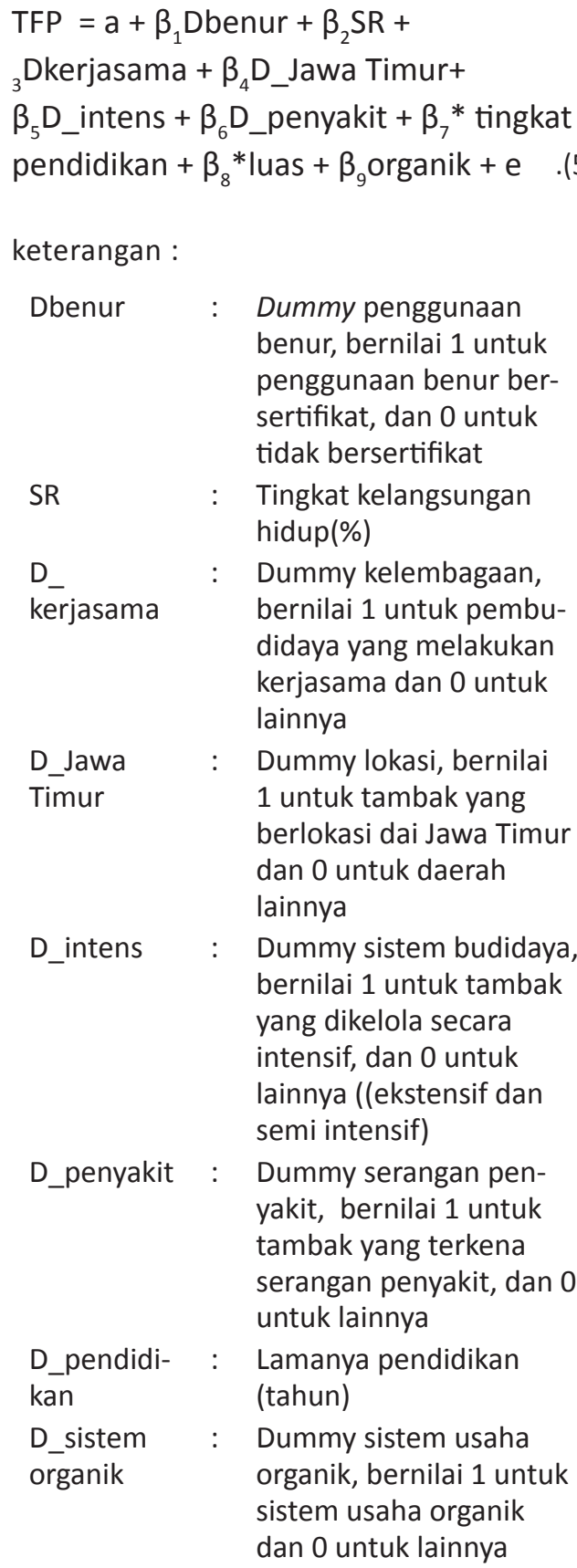

Dalam penelitian ini juga dilakukan pengujian asumsi dasar Ordinary Least square (OLS) untuk persyaratan Best Linier Under Estimate (BLUE) meliputi uji multikolinearitas, autokolerasi dan heteroskedasitas.

\section{HASIL DAN PEMBAHASAN}

\section{Kinerja Produktivitas Tambak Udang Indonesia, 1989-2008}

Pertumbuhan indeks output, indeks input, dan indeks TFP periode tahun 19892008 disajikan pada Gambar 1, sedangkan pertumbuhan per periode disajikan pada Lampiran 1. Berdasarkan Gambar, pada periode 1989-2008 indeks produksi meningkat menjadi $324.5 \%$, indeks input hampir 489.1\%, sedangkan indeks TFP relatif stagnan. Artinya, pertumbuhan output lebih disebabkan pertumbuhan input (faktor produksi) terutama pertumbuhan benur, obat-obatan, energi, dan pakan. Berikut disajikan pembahasan perkembangan output, input, dan TFP periode penelitian.

\section{Perkembangan Output}

Berdasarkan data pada Lampiran 1, pada keseluruhan periode 1989-2008, laju pertumbuhan output tertinggi terjadi pada udang vaname disusul ikan bandeng, dan udang windu. Diduga karena udang vaname memiliki produktivitas lebih tinggi. Akan tetapi, dari sisi pangsa terhadap penerimaan urutannya yaitu udang windu, udang vaname dan ikan bandeng. Udang windu memiliki pangsa terhadap total penerimaan lebih tinggi dibandingkan udang vaname dikarenakan harga jualnya relatif lebih tinggi.

Berdasarkan empat periode pengamatan, pada tahun 1994-1998 laju pertumbuhan output baik untuk udang windu, udang putih, maupun ikan bandeng bernilai negatif. Hal tersebut diduga karena belum berhasil diatasinya penyakit. Pada periode tahun 1989-1993, udang tambak terserang penyakit Monodon Baculo Virus (MBV). Kondisi tersebut berlanjut sehingga pada tahun 2000/2001 dan sampai sekarang. Menurut Widigdo (2005) akibat serangan penyakit, kuantitas ekspor tahun 2000 turun menjadi 70 ribu ton dan $90 \%$ dari 350 ribu Ha tambak dalam kondisi terlantar. 


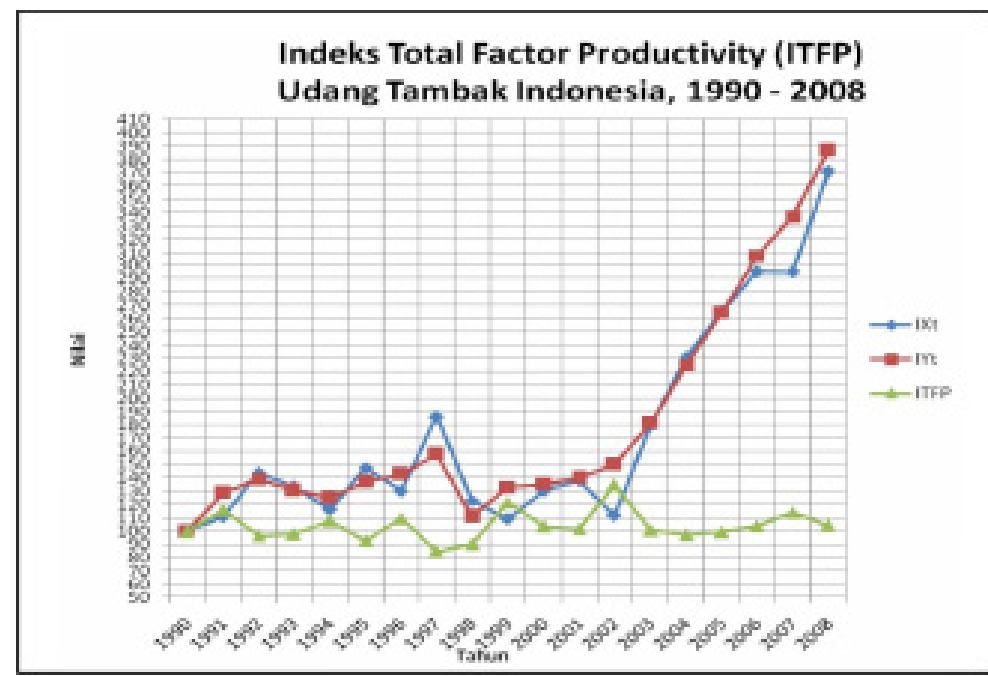

Gambar 1. Indeks TFP Udang Tambak Indonesia, 1990-2008. Figure 1. Farmed Shrimp TFP Indexes, 1990-2008.

Pada periode 1999-2003, laju pertumbuhan output menjadi positif yaitu sebesar $12.6 \%$ untuk udang windu, $6.8 \%$ untuk udang vaname, dan $8.2 \%$ untuk ikan bandeng. Peningkatan tersebut diduga karena tersedianya sumber air hasil dari pembangunan jaringan irigasi melalui dana SPL-OECF/JBIC dengan nilai sekitar Rp.300 milyar. Peningkatan juga diduga akibat perubahan status dari semula setingkat Ditjen Perikanan menjadi setingkat Kementerian (Departemen Eksplorasi Laut dan Perikanan/DELP) pada akhir tahun 1999 sehingga terdapat peningkatan anggaran. Pada periode berikutnya yaitu 2004-2008, laju pertumbuhan udang windu jauh berkurang, dan udang vaname memiliki laju pertumbuhan tertinggi. Pangsa penerimaan dari udang vaname juga meningkat, akan tetapi masih lebih rendah dibandingkan pangsa penerimaaan dari udang windu.

\section{Perkembangan Input (Faktor Produksi)}

Faktor produksi yang digunakan dalam menghitung indeks input mencakup benur, pupuk, tenaga kerja, pakan, obat-obatan, dan energi. Berdasarkan data pada Lampiran 1, pangsa pengeluaran faktor produksi terhadap biaya total terbesar adalah pakan, disusul upah, energi, benur, pupuk dan obat. Pakan merupakan penyumbang terbesar pada sistem intensif, sedangkan upah tenaga kerja merupakan penyumbang terbesar sistem usaha budidaya non intensif (semi intensif dan ekstensif).

Dari empat periode pengamatan, penggunaan benur tumbuh $53.0 \%$ per tahun pada periode 1994-1998, disusul energi $22.8 \%$ per tahun. Hal tersebut diduga karena adanya upaya intensifikasi, dan pada saat bersamaan juga terjadi serangan penyakit sehingga pembudidaya berupaya menambah kincir yang menyebabkan biaya pengeluaran untuk energi dan obat-obatan meningkat. Di lain pihak, laju pertumbuhan pakan bernilai negatif diduga karena berkurangnya masa pemeliharaan akibat terserang penyakit, dan berkurangnya penggunaan pakan akibat kenaikan harga pakan pada saat krisis moneter.

Pada periode 2004-2008 pangsa pengeluaran untuk energi meningkat karena terjadinya kenaikan harga BBM. Pergantian dari udang windu ke udang vaname juga menyebabkan terjadinya peningkatan padat 
tebar sehingga pemakaian pakan dan kincir menjadi lebih banyak. Adapun peningkatan laju pertumbuhan penggunaan obat, diduga terkait dengan serangan penyakit yang belum dapat sepenuhnya diatasi.

\section{Perkembangan TFP}

Berdasarkan Gambar 1, selama kurun waktu penelitian (periode 1989-2008), adanya rehabilitasi dan pembangunan saluran tambak melalui SPL-JBIC/INP-23 periode tahun 1999-2002 diduga mampu menahan penurunan TFP dari periode sebelumnya. Tren indeks TFP meningkat diduga karena introduksi udang vaname. Namun, pada tahun 2002 indeks TFP kembali menurun karena serangan penyakit.

Belum optimalnya pengaruh TFP tersebut diduga disebabkan beberapa faktor. Faktor tersebut yaitu serangan penyakit belum sepenuhnya dapat diatasi, dan benur belum sepenuhnya bebas penyakit dan bersertifikat. Kemampuan dan akses ke modal untuk pembudidaya skala kecil juga terbatas. Penerapan teknologi lebih bersifat anjuran dan paket teknologi yang dihasilkan oleh Unit Pelakaana Teknis (UPT) lingkup Ditjen Perikanan Budidaya dan Badan Litbang juga belum banyak diadopsi oleh pembudidaya karena keterbatasan pembiayaan.

Kegiatan Pemerintah lebih banyak kepada pemberian bantuan langsung kepada pembudidaya skala kecil, dan tidak langsung terkait dengan peningkatan produktivitas karena keterbatasan anggaran. Upaya peningkatan produktivitas yang cukup berhasil yaitu melalui IntenBerdasarkan Gambar, selama kurun waktu penelitian (periode 1989-2008), adanya rehabilitasi dan pembangunan saluran tambak melalui SPL-JBIC/INP-23 periode tahun 1999-2002 diduga mampu menahan penurunan TFP dari periode sebelumnya. Tren indeks TFP meningkat diduga karena introduksi udang vaname. Namun, pada tahun 2002 indeks TFP kembali menurun karena serangan penyakit.
Belum optimalnya pengaruh TFP tersebut diduga disebabkan beberapa faktor. Faktor tersebut yaitu serangan penyakit belum sepenuhnya dapat diatasi, dan benur belum sepenuhnya bebas penyakit dan bersertifikat. Kemampuan dan akses ke modal untuk pembudidaya skala kecil juga terbatas. Penerapan teknologi lebih bersifat anjuran dan paket teknologi yang dihasilkan oleh Unit Pelakaana Teknis (UPT) lingkup Ditjen Perikanan Budidaya dan Badan Litbang juga belum banyak diadopsi oleh pembudidaya karena keterbatasan pembiayaan.

Kegiatan Pemerintah lebih banyak kepada pemberian bantuan langsung kepada pembudidaya skala kecil, dan tidak langsung terkait dengan peningkatan produktivitas karena keterbatasan anggaran. Upaya peningkatan produktivitas yang cukup berhasil yaitu melalui Intensifikasi Tambak (Intam) yang diluncurkan tahun 1984/1985. Melalui Program tersebut terjadi peningkatan luas area pemeliharaan dari $20 \mathrm{Ha}$ di tiga propinsi menjadi $95.311 \mathrm{Ha}$ di 14 propinsi pada tahun 1998/1999 (Hasibuan, 2003). Peserta program dibentuk kelompok, dibuat tambak percontohan, disediakan fasilitas kredit, pembangunan dan pemeliharan saluran irigasi, serta dibentuknya kelembagaan pendukung seperti Perkumpulan Petani Pemakai Air (P3AT).

Pada periode berikutnya, upaya pemerintah tetap lebih banyak ke arah anjuran penggunaan teknologi dan mencakup beberapa komoditas. Program pada Ditjen Perikanan periode tahun 1990-an antara lain Peningkatan Sarana Prasarana Perikanan, Diversifikasi Pangan dan Gizi, Pengembangan Usaha Perikanan mencakup beberapa komoditas. Program tersebut berubah menjadi Intensifikasi Pembudidayaan Ikan (Inbudkan) sesuai Kepmen Kelautan dan Perikanan Nomor Kep.09/Men/2002 tanggal 26 Februari 2002. Program lebih menitikberatkan pada gerakan bersama dari berbagai pihak untuk mengembangkan usaha pembudidayaan 
ikan/udang. Program dilaksanakan atas dasar kerjasama antar anggota kelompok di dalam kawasan, yang menerapkan teknologi anjuran.

Upaya peningkatan produktivitas melalui peningkatan mutu benur mulai nampak melalui pergantian varietas dari udang windu ke udang vaname sesuai KEP.41/MEN/2001 tanggal 12 Juli 2001 tentang Pelepasan Varietas Udang Vaname sebagai Varietas Unggul. Tindak lanjutnya, pemerintah melakukan kegiatan Rekayasa Breeding Programe udang vaname di BBAP Situbondo sesuai SK Dirjen Perikanan Budidaya No.6375/ DPB.1/PB.110/2003, 23 Desember 2003 dengan produk diberi nama Vaname Nusantara-1. Pada tahun 2005 ketika Inbudkan berubah menjadi Program Peningkatan Produksi Perikanan Budidaya untuk Ekspor (Propekan), didalamnya juga mencakup pembangunan broodstock center untuk menghasilkan calon induk udang vaname di Situbondo dan udang windu di Jepara. Upaya lain yang dilakukan berupa Bantuan Selisih Harga Benih ikan (BSHBI) kepada pembudidaya ikan skala kecil sebesar Rp.24.97 milyar pada tahun 2006, Rp.23.45 milyar pada tahun 2007, sebesar Rp.35.30 milyar pada tahun 2008, dan Rp.60 milyar pada tahun 2009 (DKP, 2009).

Menurut Kusnendar (2003) dalam Tajerin (2007), salah satu faktor yang menyebabkan kekurangberhasilan program revitalisasi tambak adalah pendekatan yang digunakan dalam implementasi kebijakan kurang bersifat holistik, kurang melibatkan semua stakeholders yang terkait dengan program tersebut. Hal tersebut sejalan dengan Platon (1998) dalam Saloyo (2000) bahwa perlu pendekatan total sebagai suatu sistem untuk memperbaiki industri udang di Philipina yang mencakup teknologi, modal, kebijakan, penegakan aturan, dan kemauan politik.

\section{Hasil Konfirmasi TFP pada Tingkat Lapang}

\section{Kinerja Produktivitas}

Hasil perhitungan penyebaran angka indeks TFP disajikan pada Tabel 1 dengan nilai berkisar dari $0.03-4.40$ dan rata-rata 1.03. Arti angka indeks TFP secara individu untuk tiap petakan dalam studi ini mencerminkan perbedaan produktivitas dibandingkan nilai ratarata setiap petakan. Petakan tambak yang mempunyai nilai 1.37 artinya mempunyai TFP $37 \%$ lebih tinggi dibandingkan rata-rata.

Hasil analisis pada tingkat lapang untuk mengkonfirmasi analisis TFP pada tingkat nasional, harus diinterpretasikan secara hati-hati karena pada saat penelitian, banyak pembudidaya udang mengalami

Tabel 1. Kisaran Angka Indeks TFP berdasarkan lokasi dan Sistem Usaha.

Table 1. TFP Indexes by Location and Culture Systems.

\begin{tabular}{lcccc}
\hline Variabel/Variables & Mean & Min & Max & Stdev \\
\hline $\begin{array}{l}\text { Lokasi/Location } \\
\text { - Jawa Timur/East Java }\end{array}$ & 1.0000 & 0.0919 & 3.0596 & 0.7378 \\
$\quad \begin{array}{l}\text { - Di luar Jawa Timur/ Outside } \\
\quad \text { East Java }\end{array}$ & 1.0472 & 0.0333 & 4.4054 & 0.5122 \\
$\begin{array}{l}\text { Sistem Usaha /Farming System } \\
\text { - Intensif/Intensive }\end{array}$ & 1.3717 & 0.6472 & 4.4054 & 0.4900 \\
- Non Intensif/Non intensive & 0.4318 & 0.0333 & 1.4681 & 0.2889 \\
\hline
\end{tabular}

Sumber: data primer diolah/source: primary data, processed 
kegagalan produksi akibat serangan penyakit. Kondisi tersebut didukung dari nilai dummy serangan penyakit yang menurunkan produksi dan signifikan pada selang kepercayaan $1 \%$. Jenis penyakit menyerang udang pada kisaran umur pemeliharaan antara 30 sampai dengan 120 hari.

\section{Faktor-Faktor yang Mempengaruhi TFP}

Hasil perhitungan angka indeks TFP tiap petak tersebut, selanjutnya diregresikan untuk mengetahui faktor-faktor yang mempengaruhinya. Faktor-faktor tersebut akan terkait dengan upaya penurunan biaya produksi melalui peningkatan efisiensi, skala usaha, dan perubahan teknologi. Pada studi ini, potensi penurunan biaya produksi antara lain diperoleh melalui upaya intensifikasi dan penggunaan benur unggul. Faktor lainnya adalah terkait dengan peningkatan harga jual. Potensi peningkatan harga jual antara lain melalui sistem kerjasama antara pembudidaya, dan sistem budidaya udang organik. Dummy penggunaan udang vaname yang mempunyai produktivitas lebih tinggi, tidak termasuk variabel penjelas karena terjadi multikolinearitas dengan serangan penyakit. Hasilnya disajikan pada Tabel 2.

Berdasarkan arah dan besaran, variabel yang berpengaruh positif terhadap TFP dan signifikan yaitu: penggunaan benur bersertifikat, dummy intensifikasi, dummy lokasi, dan tingkat pendidikan. Variabel penjelas yang signifikan dan berpengaruh negatif terhadap TFP yaitu serangan penyakit, dan dummy pembudidaya yang melakukan kerjasama. Varibel yang berpengaruh positif tapi tidak signifikan yaitu sistem budidaya udang secara organik, sedangkan luas area yang diusahakan berpengaruh negatif terhadap TFP. Berikut disampaikan penjelasan dari beberapa variabel tersebut.

Tabel 2. Faktor-Faktor yang Diduga Berpengaruh Terhadap TFP Tambak.

Table 2. Factors that Influencing Shrimp Farmed TFP Index.

\begin{tabular}{lcccc}
\hline \multicolumn{1}{c}{ Variabel/Variables } & $\begin{array}{c}\text { Parameter dugaan/ } \\
\text { Estimation } \\
\text { Parameter }\end{array}$ & $\begin{array}{c}\text { Standard } \\
\text { error }\end{array}$ & t Value & Pr > |t | \\
\hline $\begin{array}{l}\text { Intersep/Intercept } \\
\text { Benur bersertifikat/Certified Fry }\end{array}$ & 0.125409 & 0.175591 & 0.71 & 0.4762 \\
$\begin{array}{l}\text { Tingkat kelangsungan hidup/ } \\
\text { Survival rate (\%) }\end{array}$ & 0.25318 & 0.134739 & 1.88 & 0.0621 \\
$\begin{array}{l}\text { Dummy Serangan penyakit/ } \\
\text { Dummy Disease outbreak }\end{array}$ & 0.11982 & 0.192625 & 0.62 & 0.5348 \\
$\begin{array}{l}\text { Dummy pengelolaan intensif/ } \\
\text { Dummy of Intensification }\end{array}$ & -0.21509 & 0.083664 & -2.57 & 0.0111 \\
$\begin{array}{l}\text { Dummy sistem budidaya } \\
\text { organik/Dummy of Organis }\end{array}$ & 0.646425 & 0.165823 & 3.9 & 0.0001 \\
$\begin{array}{l}\text { Culture System } \\
\begin{array}{l}\text { Dummy lokasi di Jawa Timur/ } \\
\text { dummy Eas Java Location }\end{array}\end{array}$ & 0.004672 & 0.130103 & 0.04 & 0.9714 \\
$\begin{array}{l}\text { Dummy lama pendidlkan/ } \\
\text { Dummy length of education }\end{array}$ & 0.31735 & 0.082252 & 3.86 & 0.0002 \\
$\begin{array}{l}\text { Luas area yang diusahakan/ } \\
\text { Farm size }\end{array}$ & 0.023438 & 0.012902 & 1.82 & 0.0712 \\
$\begin{array}{l}\text { Dummy Kerjasama/Dummy of } \\
\text { Cooperation }\end{array}$ & -0.00387 & 0.004914 & -0.79 & 0.4324 \\
\hline
\end{tabular}

Sumber: data primer diolah/Source: primary data, processed Keterangan: $\mathrm{R}^{2}=76.24 \%$, Adjusted R-Squared $=74.84 \%$ 
Varibel yang berpengaruh positif tapi tidak signifikan yaitu sistem budidaya udang secara organik, sedangkan luas area yang diusahakan berpengaruh negatif terhadap TFP. Berikut disampaikan penjelasan dari beberapa variabel tersebut.

\section{Serangan Penyakit}

Berdasarkan Tabel 2, serangan penyakit berpengaruh negatif dan signifikan terhadap TFP. Udang tambak termasuk yang rentan terkena serangan penyakit. Jenis virus yang menyerang tersebut antara lain: White Spot Syndrome Virus (WSSV), Taura Syndrome Virus (TSV), dan Infectious Myo Necrosis Virus (IMNV). Sebagai ilustrasi, produksi udang tambak tahun 2009 hanya sebanyak 336.0 ribu ton dari target 540.0 ribu ton, atau turun dari capaian tahun 2008 sebanyak 409.6 ribu ton. Penyebabnya, udang di dua wilayah utama yaitu Lampung dan Jawa Timur terkena serangan penyakit yang disebabkan oleh virus.

Serangan penyakit tersebut tidak hanya menyerang udang yang dipelihara oleh tambak perorangan, akan tetapi termasuk juga perusahaan terintegrasi. Kuantitas produksi perusahaan terintegrasi dibawah PT. CP Prima Grup, pada tahun 2008 mencapai sekitar 97 ribu ton, sedangkan pada tahun 2009 hanya sekitar 57 ribu ton. Produktivitas udang turun dari 20 ton per $\mathrm{Ha}$ menjadi 17 ton - 18 ton per $\mathrm{Ha}$.

Dari hasil pengamatan lapang, sekitar $70 \%$ responden menyatakan faktor yang paling menentukan keberhasilan budidaya udang adalah terhindarnya dari serangan penyakit. Responden menyebutkan bahwa rata-rata udang mereka mulai terserang penyakit pada umur pemeliharaan 30 sampai dengan 60 hari.

Upaya yang dilakukan untuk mengatasi pengurangan risiko serangan penyakit dilakukan dengan mengganti varietas yang digunakan dari udang windu ke udang vaname. Upaya lainnya yaitu melalui penurunan padat tebar. Udang vaname pada awalnya resisten terhadap sekitar 12 jenis virus, akan tetapi sejalan perkembangan, akhirnya udang vaname pun serupa dengan udang windu yaitu tidak tahan terhadap penyakit. Dalam rangka menghindari serangan penyakit, seorang pembudidaya udang di Sidoarjo melakukan inovasi dengan memanen udang pada umur pemeliharaan 60 hari dan dijual dengan ukuran kecil (size sekitar 100 ekor/ $\mathrm{kg}$ ) untuk pasar domestik.

Studi ini tidak mengamati dampak serangan penyakit dari aspek ekonomi. Akan tetapi, hasil studi lain seperti Valderrama dan Engle (2004) yang menganalisa dampak virus TSV dan WSP di Honduras menggunakan pendekatan linier programming menunjukkan bahwa penyakit menurunkan Net Farm Income (NFI) 84\% dibandingkan tambak yang tidak terkena penyakit, sedangkan hasil simulasi berupa pencegahan penyakit akan meningkatkan NFI $47 \%$.

Salah satu kendala penanganan penyakit yaitu belum adanya kerjasama antar sesama pembudidaya apabila udang tambak mereka terkena penyakit. Oleh karena itu penelitian mengenai penyakit harus memperoleh perhatian yang serius. Dengan demikian perlu pengaturan mengenai padat penebaran untuk menghindari degradasi lingkungan akibat pakan berlebih, dan tata ruang perlu diperhatikan sehingga kawasan tersebut benar-benar peruntukannya untuk zona budidaya.

\section{Benur Bersertifikat}

Berdasarkan Tabel 2, penggunaan benur bersertifkat berkorelasi positif terhadap produktivitas (TFP). Benur bermutu akan meningkatkan tingkat kelangsungan hidup dan bobot biomasa. Sertifikasi benur merupakan bagian dari upaya mendorong penggunaan benur bermutu. Hasil analisis menunjukkan bahwa penggunaan benur bersertifikat bernilai positif. Namun secara umum penggunaannya oleh pembudidaya sistem usaha non intensif 
(ekstensif dan semi intensif) masih terbatas, sehingga pengaruh benur terhadap produktivitas rendah. Terbatasnya penggunaan benur bermutu oleh pembudidaya udang non intensif antara lain terkendala masalah harga. Untuk itu telah dilakukan juga kegiatan Bantuan Selisih Harga Benih ikan (BSHBI) kepada pembudidaya ikan skala kecil.

Dari sisi harga, keberadaan benur vaname Nusantara sangat membantu pembudidaya karena relatif lebih murah. Sebagai perbandingan, benur vaname F1 hasil induk dari impor dijual dengan harga Rp.31/ekor, sedangkan Vaname Nusantara hanya Rp.18/ekor. Akan tetapi, sekitar $10 \%$ responden belum yakin penuh dengan Vaname Nusantara karena tingkat keragaman udang yang dihasilkan relatif lebih tinggi dibandingkan penggunaan benur vaname F1 induk impor. Pada saat panen, udang berukuran kecil hanya sekitar $5 \%$ jika menggunakan F1 dari induk impor, sedangkan vaname Nusantara dapat mencapai $20 \%$.

Terkait merebaknya penyakit udang, dua responden menduga hal tersebut disebabkan kurangnya pengawasan terhadap hatchery. Tingginya permintaan benur pada tahun 2008 yang menyebabkan produksi udang tertinggi, diduga menyebabkan beberapa hatchery menggunakan kembali induk yang seharusnya sudah afkir. Akibatnya benur udang vaname yang berasal dari induk impor yang semula bersifat Specific Pathogen Free (SPF) terhadap virus WSSV, TSV, IMNV, dan IHHNV, terkena juga serangan penyakit. Benur yang SPF setelah ditebar di tambak tidak semuanya berhasil panen dengan baik dimungkinkan juga karena induk impor telah mengalami penurunan kualitas, dan semakin rusaknya lingkungan perairan Indonesia untuk budidaya udang.

Pada budidaya udang, kualitas benur memegang peranan penting, karena akan berdampak pada hasil dan kondisi lingkungan. Akan tetapi, belum semua pembudidaya menyadari bahwa akibat kesalahan pemilihan benur dapat menyebabkan efek berantai. Kesalahan menduga populasi dapat berakibat fatal, yaitu pakan yang diberikan meningkat sehingga Feed Conversion Ratio (FCR) tinggi.

\section{Intensifikasi}

$\begin{array}{lcrr}\text { Sistem } & \text { usaha secara intensif } \\ \text { mempunyai nilai TFP lebih } & \text { tinggi } \\ \text { dibandingkan dengan sistem } & \text { usaha } \\ \text { non-intensif. } & \text { Berdasarkan data pada }\end{array}$ penelitian ini (Lampiran 2), intensifikasi berpengaruh positif terhadap TFP diduga karena tingkat kelangsungan hidup sistem intensif lebih tinggi karena penggunaan benur bermutu. Tingkat produksi per $\mathrm{Ha}$ di lokasi studi berkisar rata-rata 13.1 ton/ha dengan kisaran dari 3.0 ton sampai dengan 25.5 ton per Ha.

Pada sistem usaha intensif kemampuan pembudidaya juga lebih tinggi, dan pakan yang digunakan juga lebih bermutu (kandungan protein lebih tinggi) dibandingkan dengan pakan pada sistem non intensif, namun penggunaan pakan berlebih berpotensi mencemari lingkungan, sehingga dapat meningkatkan risiko serangan penyakit.

Salah satu kendala dalam budidaya udang intensif adalah relatif mahalnya harga pakan. Harga pakan Indonesia 15\% lebih tinggi dibandingkan Thailand, dan $40 \%$ lebih tinggi dibandingkan China (IFC, 2006). Hal tersebut diduga terkait belum efisiennya pemasaran dan terkonsentrasinya pabrik pakan, salah satunya PT CP Prima yang mempunyai pangsa pasar nasional sekitar 40\%. Berdasarkan data laporan tahunan, PT CP Prima mengeluarkan produk pakan udang dengan merk Irawan, Bintang dan PT CP Marine dan produksi tahun 2007 sebanyak 128.519 ton dan tahun 2008 sebanyak 181.398 ton. Harga pokok penjualan tahun 2007 adalah Rp.4.639/ kg dan Rp.5.963 untuk tahun 2008, sedangkan harga jual pada tahun 2007 adalah Rp.8.200/ kg dan Rp.8.593 pada tahun 2008. 
Aisya et al. (2005) menganalisis dampak kebijakan insentif dan kinerja pasar udang Indonesia menggunakan pendekatan PAM. Hasilnya, udang Indonesia mempunyai keunggulan komparatif, dan usaha intensif paling efisien dalam penggunaan biaya domestik. Selain itu, terjadi transfer penerimaan dari petani udang intensif dan semi-intensif ke konsumen dan produsen input berturut-turut $1.83 \%$ dan $1.92 \%$ dari masing-masing pendapatan. Sebaliknya kebijakan ini menyebabkan penerimaan untuk pembudidaya udang tradisional, menjadi $14.07 \%$ lebih tinggi dibandingkan dengan tanpa kebijakan.

Walaupun, intensifikasi meningkatkan TFP, namun berdasarkan proporsi, mayoritas tambak udang di Indonesia dikelola secara ekstensif sehingga secara keseluruhan nilai TFP-nya rendah. Dari $200.000 \mathrm{Ha}$ tambak di Indonesia, komposisinya lebih dari $75 \%$ adalah tambak ekstensif dengan produktivitas kurang dari 500 kg per Ha. Sekitar 15\% merupakan tambak semi-intensif dengan produktivitas 1 - 2 ton per $\mathrm{Ha}$, dan sisanya $10 \%$ tambak intensif dengan produktivitas lebih dari 3 ton per Ha. Dalam perkembangan selanjutnya, komposisi tambak intensif makin berkurang seiring tingginya risiko terjadinya serangan penyakit. Ketika aspek ekonomi, sosial, dan lingkungan menjadi kriteria, hanya tambak semi intensif yang memenuhi ketiga kriteria tersebut (Primavera, 1991). Diprediksi karena keterbatasan modal dan managemen maka sistem tambak ekstensif yang berkembang pesat di Indonesia.

Dibandingkan tambak di Thailand, mayoritas tambak di Indonesia dikelola secara ekstensif dengan produktivitas rendah. Ling et al. (1999) berdasarkan survey tahun 1994/1995 untuk sistem intensif menemukan tambak di Thailand memiliki produktivitas rata-rata mencapai 10,727 ton/Ha, sedangkan Indonesia hanya 4,390 ton/Ha. Pada sistem budidaya secara ekstensif, produktivitas per $\mathrm{Ha}$ di Thailand mencapai $394 \mathrm{Kg} / \mathrm{Ha}$ sedangkan Indonesia hanya rata-rata $162 \mathrm{Kg} / \mathrm{Ha}$. Tambak udang di Thailand juga dapat berproduksi rata sekitar 2,4 kali per tahun, sedangkan Indonesia hanya 2,0 (dua) kali per tahun. Menurut Wyban (2007) Thailand menjadi leader ekspor udang karena produktivitas tinggi. Faktor-faktor keberhasilan industri udang yaitu mengurangi ketergantungan bahan impor untuk komponen pakan, peralatan tambak, dan BBM dari $25-50 \%$ menjadi $25 \%$.

Hasil studi akan berbeda jika menambahkan faktor lingkungan untuk menghitung TFP. Studi Martinez-Cordero dan Leung (2005) yang menghitung TFP dan efisiensi teknis menggunakan pendekatan Malmquist Index untuk tambak semi-intensif di Meksiko periode 1994, 1996-1998, dan 2001-2003, mendapatkan hasil perhitungan yang lebih rendah dibandingkan perhitungan secara tradisional, jika memasukan faktor lingkungan kedalam perhitungan.

\section{Pengaruh Lokasi Pemeliharaan}

Pengaruh TFP akibat perbedaan lokasi geografis dari kondisi agroklimat kurang tergali dalam studi ini. Akan tetapi berdasarkan Lampiran 3 yaitu perbandingan untuk pengusahaan tambak di Jawa Timur dengan tambak di luar Jawa Timur, nampak bahwa nilai dummy TFP lokasi (Jawa Timur) bernilai positif. Pada studi ini, rata-rata udang ukuran panen di Jawa Timur lebih besar dibandingkan non Jawa Timur, sehingga memperoleh harga jual yang lebih tinggi yaitu Rp.47.247, sedangkan diluar Jawa Timur rata-rata hanya Rp.34.275. Salah satu penyebab tingginya harga udang di Jawa Timur juga disebabkan budidaya udang organik. Rendahnya padat penebaran yang digunakan menyebabkan pertumbuhan biomas per ekor menjadi lebih tinggi sehingga harga jual menjadi lebih tinggi.

Salah satu upaya yang meningkatkan harga yang dilakukan oleh Dinas Kelautan dan Perikanan Provinsi Lampung antara lain menyusun harga udang secara harian 
untuk petambak plasma dengan menyesuaikan pada harga udang di Jawa Timur. Di Provinsi Lampung, Unit Pengolah Udang juga terbatas sehingga pembudidaya udang dari Lampung lebih senang menjual ke pedagang pengumpul/ suplier/eksportir dari Cirebon seperti Ibu Khodijah dan Ramsikin, Rohamah, PT HJG dari Jakarta, atau PT. BMI dari Surabaya.

\section{Kemampuan SDM}

Tingkat pendidikan pembudidaya udang berkorelasi positif terhadap peningkatan TFP (Tabel 2). Pada studi ini, rata-rata tingkat pendidikan pada sistem intensif yaitu 16.9 tahun, sedangkan pada sistem non intensif rata-rata 10.9 tahun. Dengan demikian, tingginya nilai TFP untuk sistem intensif diduga karena tingkat pendidikan juga lebih tinggi. Akan tetapi, secara umum berdasarkan data hasil Survey Sosek Perikanan DJPB pada tahun 2005 komposisi pembudidaya berdasarkan pendidikan yaitu: tidak tamat sekolah sebanyak 3.2\%, tamatan SD sebanyak $43.6 \%$ dan hanya $7.7 \%$ yang merupakan lulusan Perguruan tinggi (Ditjen Perikanan Budidaya, 2005).

Kondisi tersebut jauh berbeda dengan di Thailand, Sriwichailamphan (2007) melakukan studi mencakup 350 orang pembudidaya udang menemukan $28.7 \%$ respondennya berpendidikan sarjana dan master $2.6 \%$. Pendidikan pembudidaya udang, lebih tinggi dibandingkan rata-rata pendidikan peternak dan pembudidaya ikan pinapple. Mayoritas pembudidaya berada pada usia produktif yaitu berusia antara $31-40$ yaitu sebanyak $36 \%$. Sebanyak $56 \%$ dari 350 responden telah menerapkan Good Aquaculture Practices (GAP) dan $44 \%$ masih menolaknya. Menggunakan model logit diketahui bahwa pembudidaya udang di Thailand mengadopsi GAP, terutama karena tingkat pendidikan. Pemerintah Thailand meningkatkan keterampilan/pengalaman pembudidaya melalui pelatihan secara langsung, pelatihan mandiri melalui $C D$, dan internet (Bluffstone et al, 2006).
Pengembangan udang di Thailand juga melibatkan lebih dari 800 ilmuwan dengan 300 publikasi internasional, dan tujuh universitas menyediakan pelatihan udang. Dukungan pemerintah dalam pemanfaatan bidang bioteknologi selama periode 20032007 sebanyak US\$ 18 juta untuk impor induk dan domestikasi udang windu (Tanticharoen et al, 2008).

\section{Luas Area Yang Diusahakan}

Pada studi ini, luas area yang diusahakan berpengaruh negatif terhadap TFP. Terjadinya hal tersebut diduga karena: (i) keterbatasan kemampuan managerial dan supervisi tenaga kerja seiring besarnya skala usaha, (ii) perubahan dari penanggulangan risiko seiring dengan peningkatan skala usaha, serta (iii) keterbatasan penguasaan terhadap faktor alam pada penggunaan lahan yang semakin luas. Pada lahan luas, usaha budidaya cenderung lebih bersifat ekstensif. Semakin luas tambak yang dimiliki, makin sedikit buruh per area yang dibutuhkan.

Sesuai dengan studi ini, hasil studi Gunaratne dan Leung (1996) yang mengamati di tujuh negara, luas tambak berkorelasi negatif terhadap efisiensi pada sistem usaha ekstensif dan semi intensif, namun berkorelasi positif pada usaha intensif.

\section{Aspek Kelembagaan (Kerjasama)}

Dari aspek kelembagaan, sistem kerjasama berpotensi meningkatkan harga jual sehingga TFP-pun diharapkan lebih tinggi. Adanya kerjasama memungkinkan permasalahan umum yang sering dihadapi oleh eksportir berupa kelangkaan bahan baku semestinya tidak terjadi. Namun, hasil studi ini menunjukkan sistem kerjasama justru berpengaruh negatif terhadap TFP.

Hasil wawancara dengan beberapa responden pembudidaya, menunjukkan ketidakcocokan dengan sistem kerjasama karena merasa lebih banyak berada pada 
pihak yang dirugikan. Beberapa responden pernah melakukan sistem kerjasama akan tetapi pada saat panen, pembeli mengulurngulur waktu pembelian, sedangkan biaya pakan makin meningkat jika masa pemeliharaan dilanjutkan.

Hal yang sama juga ditemui pada sistem budidaya udang organik, pembudidaya merasa kesulitan merubah budaya kerja seperti tuntutan importir Jepang yang terkenal "cerewet" dalam hal mutu dan cara panen. Pemberian es untuk menjaga mutu tidak boleh dilakukan di rumah, melainkan harus ditambak serta langsung disegel. Selain itu, perbedaan harga jual udang organik dengan udang non organik sebesar Rp.7.000 dianggap kurang mencukupi. Selisih harga sebesar Rp.12.000/kg baru dianggap dapat menutupi besarnya biaya yang dikeluarkan antara lain untuk panen udang organik. Kadang perusahaan juga tidak membeli semua udang dan hanya membeli sesuai dengan ukuran yang dibutuhkan. Jika udang berukuran besar, misalnya size 15-23, terkadang mereka tidak membelinya. Jika tetap dibeli, mereka membeli murah dibandingkan pembei lainnya karena mereka tidak terlalu membutuhkan.

Di pihak lain, beberapa pedagang besar/supplier tidak melakukan ikatan kerja sama (beli putus) dengan pertimbangan agar tidak ada kewajiban membeli ketika harga tinggi. Bagi suplier dengan tanpa ikatan berarti mereka dapat menjual ke UPI mana saja yang memberikan penawaran lebih tinggi. Akibatnya, pada musim tertentu ukuran udang yang lebih kecil dapat dikenakan harga yang lebih mahal.

Studi lain terkait kemitraan juga menunjukkan hasil yang memiliki kemiripan. Cahyono et al, (2007) yang mengkaji kemitraan ikan nila dengan PT Aqua Farm menyimpulkan bahwa program kemitraan belum berjalan sesuai dengan harapan yaitu pendapatan pembudidaya ikan mitra lebih kecil dari pembudidaya ikan non mitra. Bagi pembudidaya ikan, program kemitraan membantu pembudidaya ikan dalam pengadaan benih, pemberian pinjaman modal berupa benih dan pakan, serta keterjaminan pasar dan kepastian harga. Kendala yang ditemukan antara terjadinya penjualan ikan nila keluar perusahaan, pembayaran hasil panen mitra yang terlalu lama, tidak adanya kerjasama kerja tertulis yang mempunyai dasar hukum.

Belum optimalnya sistem kerjasama di atas terkait juga dengan tingginya risiko baik risko produksi maupun risiko harga. Adanya serangan penyakit menyebabkan produksi kurang dapat diprediksi sehingga harga udang berfluktuasi. Di Thailand, menurut Globefish (2011), banjir yang terjadi menyebabkan hilangnya sekitar 50.000 sampai dengan 60.000 ton udang yang menyebabkan kenaikan harga sampai $40 \%$. Hal tersebut mendorong pembudidaya udang beralih dari contract farming menjadi spot prices dan pembayaran tunai.

Faktor lain yang diduga menyebabkan terjadinya fluktuasi harga antara lain: terkonsentrasinya ekspor udang Indonesia pada negara tertentu, atau eksportir/cold storage sebagai pembeli membentuk suatu kekuatan yang monopsonistis (Suryana, 1989). Struktur pasar di tingkat pedagang pengumpul dapat dikatakan berbentuk pasar oligopsoni. Struktur pasar di tingkat pedagang besar dicirikan oleh kedudukan yang lemah dari pembudidaya dan pedagang pengumpul.

Studi Oktaviani et al. (2008) di Sulawesi Selatan terkait dengan risiko dan keuntungan, diperoleh hasil bahwa tidak ada pembagian risiko antara pembudidaya ikan, pedagang pengumpul, dan koordinator. Berdasarkan analisis AHP: sumberdaya merupakan hal paling penting, disusul teknologi. Strategi terbaik yaitu menjalin kerja sama antara pembudidaya dan pedagang perantara. Hal ini senada dengan hasil studi USAID (2006) di Bangladesh yang menemukan keuntungan yang diperoleh kurang "merata" antar lembaga pemasaran. Pedagang menengah dan eksportir menerima bagian lebih besar dibandingkan bagian yang diterima pembudidaya udang dan nelayan. 


\section{KESIMPULAN DAN IMPLIKASI KEBIJAKAN}

Pertumbuhan udang tambak Indonesia periode 1989-2008 lebih karena pertumbuhan input/faktor produksi bukan karena pertumbuhan TFP, disebabkan belum dapat diatasinya masalah penyakit. Hasil konfirmasi pada tingkat lapang terhadap 163 petak tambak, serangan penyakit berpengaruh negatif dan signifikan terhadap TFP. Penggunaan benur bersertifkat, intensifikasi, dan tingkat pendidikan berkorelasi positif terhadap TFP, akan tetapi kondisi riil di Indonesia secara umum berbeda. Mayoritas tambak dikelola non intensif, penggunaa benur bersertifikat masih terbatas, dan tingkat pendidikan pembudidaya juga relatif rendah. Studi ini juga menunjukkan bahwa sistem kerjasama antara pembudidaya dengan lembaga pemasaran lainnya dan luas area yang diusahakan berpengaruh negatif terhadap TFP. Belum optimalnya sistem kerjasama diduga terkait dengan risiko produksi dan risiko harga, sedangkan luas area terkait dengan keterbatasan kemampuan managerial dan supervisi tenaga kerja seiring meningkatnya skala usaha. Berdasarkan geografis, tambak udang di provinsi Jawa Timur berkorelasi positif terhadap TFP dibandingkan di luar Jawa Timur karena ukuran lebih besar sehingga harga jual lebih tinggi.

Terkait hal-hal di atas, implikasinya pemerintah perlu memprioritaskan upaya penanganan penyakit melalui peningkatan anggaran riset, penyediaan benur bermutu melalui penambahan anggaran untuk kegiatan broodstock center udang vaname di Karang Asem dan udang windu di BBPAB Jepara. Hal lain yang diperlukan adalah peningkatan kemampuan SDM pembudidaya udang melalui pelatihan terkait penyakit, dan manajemen tambak. Peningkatan pengawasan penggunaan induk udang di hatchery dan penambahan anggaran irigasi juga penting. Aturan mengenai padat penebaran juga perlu diperhatikan agar industri tambak udang berkelanjutan. Hal lain yang perlu diperhatikan Pemerintah adalah terkait akurasi data sehingga tidak menimbulkan kesimpangsiuran.

\section{DAFTAR PUSTAKA}

Anonimous. 2004. Strategi Peningkatan Daya Saing Komoditas Perikanan. Laporan Akhir Proyek Perencanaan Kebijakan Kelautan dan Perikanan. Departemen Kelautan dan Perikanan, Jakarta.

. 2006. Rencana Strategis Perikanan Budidaya 2005-2009 (Edisi Revisi).

. 2007. Neraca Bahan Makanan Sektor Perikanan Tahun 2005.

Statisitik Perikanan Indonesia 1989-2008. Departemen Pertanian, Jakarta.

. Survey Perusahaan Perikanan (berbagai edisi).

Asche, F., K.H. Roll, and R. Tveteras. 2007. Productivity Growth in the Supply Chain-Another Source of Competitiveness for Aquaculture. Marine Resource Economics, 22:329-334.

Aisya, L.K., S. Koeshendrajana, dan K. Karyasa. 2005. Analisis Dampak Kebijakan Insentif dan Kinerja Pasar udang Indonesia Menghadapi Era Liberalisasi Perdagangan. Dalam Alim Isnansetyo et al. (Editor) Prosiding Seminar Nasional Tahunan Hasil Penelitian dan Perikanan dan Kelautan 2005. Jurusan Perikanan dan Kelautan Fakultas Pertanian Universitas Gajah Mada, Yogyakarta.

Cahyono, B., Dinarwan, dan Nani Farmayanti. 2007. Kajian Program Kemitraan Usaha (Kasus PT Aqua Farm Nusantara dengan Kelompok Tani ikan di Kecamatan Kalasan, Kabuapaten Sleman, DIY. Buletin Ekonomi Perikanan Vol.7 (2): 38-50.

PT. Central Proteina Prima Tbk. 2009. Laporan Tahunan 2008/Annual Report 2008. 
Devi, K.U. dan Y.E. Prasad. 2006. A Logistic Regression of Risk Factors for Disease Occurrence on Coastal Andhra Shrimp Faros. India Journal of Agricultural Economics, 61(1):123-132

Diop, H., R.W. Harrison, and W.R. Keithly, Jr. 1999. Impact of Increasing Imports on the United States Southeastern Region Shrimp Processing Industry 1973-1996. Selected paper for Presentation at the August 8-11 Annual Meeting of the American Agricultural Economics Association in Nashville, Tennessee.

FAO Globefish. 2011. Shrimp Supply is lower in the First Half of 2011. http://www. globefish.org/shrimp-auqust-2011.html (diakses tanggal, 10 Oktober 2011).

Fuglie, K. O. 2004. Productivity Growth in Indonesian Agriculture, 1961-2000. CIPESEAP, Bogor.

Gunaratne, L.H.P and P.S. Leung. 1996. Asian Black Tiger Shrimp Industry: A MetaProduction Frontier Analysis. In Leung and Sharma (Editors). Economic and Management of Shrimp and Carp Farming in Asia: A Collection Researh Paper. Network of Aquaculture Centres in Asia-Pacific (NACA), Bangkok.

Hutabarat, B., Hardoko, B. Sayaka, dan K.S. Indraningsih. 2000. Analisis Daya Saing dan Prospek Pasar Ekspor Hasil Perikanan Andalan Menunjang Protekan 2003. Laporan Hasil Penelitian. Pusat Penelitian Sosial Ekonomi Pertanian, Badan Penelitian dan Pengembangan Pertanian, Departemen Pertanian, Jakarta.

International Finance Corporation (IFC). 2006. Improving Indonesia's Competitiveness: Case Study of Textile and Farmed-Shrimp Industries. Volume 1. Foreign Investment Advisory Service.A Joint Facility of the International Finance Corporation and the World Bank.

International Finance Corporation (IFC). 2007. Moving Toward Competitiveness: A Value Chain Approach. The World Bank Group.
Kusumastanto, T., C. M. Jolly, and C. Muluk, 1996. Investment Analysis for Indonesian Shrimp Aquaculture. Journal of Applied Aquaculture, 6(4):1-14.

Leung, P. S. and L. H. P. Gunaratne. 1996. Intercountry Productivity Comparison of Black Tiger Shrimp Culture. In Leung and Sharma (Editors). Economic and Management of Shrimp and Carp Farming in Asia: A Collection Researh Paper. Network of Aquaculture Centres in Asia-Pacific (NACA), Bangkok.

Martinez-Cordero, F. J., W. J. Fitzgerald, dan P. S. Leung. 1999. Evaluation of Productivity in Extensive Aquaculture Practices Using Interspatial TFP Index, Sulawesi, Indonesia. Asian Fisheries Science, 12: 223-234.

Martinez-Cordero, F. J. and P. S. Leung. 2005. Production Performance Indicators with Externalities: EnvironmentallyAdjusted Productivity and Efficiency Indicators of a Sample of SemiIntensive Shrimp Farms in Mexico. 95 ${ }^{\text {th }}$ EAAE Seminar, Civitavecchia (Rome), 9-11 December 2005 Editor: Kenneth J. Thomson and Lorenzo Venzi.

Maulana, M, 2004. Peranan Luas Lahan, Intensitas Pertanaman dan Produktivitas sebagai Sumber Pertumbuhan Padi Sawah di Indonesia. Jurnal Agro ekonomi, 22(1):74-95.

Oktaviani, R., N. Nuryartono, T. Novianti, dan M. I. Irfany. 2008. Investigation of Contract Farming Options for Shrimp Production. Working Paper Series. No.07/A/III/08.

Primavera, J.H. 1997. Socio-Economic Impacts of Shrimp Culture. Aquaculture Research, 28: 815-827.

Suryana, A., H. P. Saliem dan A. Djauhari. 1989. Penelitian Pemasaran dan Keunggulan Komparatif Ekspor Komoditi Pertanian (Kelayakan Produksi dan Pemasaran udang Di Jawa Timur dan Sulawesi Selatan). Pusat Penelitian Agro Ekonomi, Badan Litbang Pertanian, Departemen Pertanian. Bogor. 
Sriwichailamphan, T. 2007. Global Food Chains and Environment: Agro-Food Production and Processing in Thailand. Ph.D Dissertation. Wageningen: Wageningen Universiteit.

Tajerin. 2007. Efisiensi Teknis Usaha Budidaya udang di Lahan Tambak dengan Teknologi Intensifikasi Pembudidayaan ikan. Jurnal Ilmu-IImu Perairan dan Perikanan Indonesia, 14 (1):1-11.

Taukhid, S., Partasasmita, J. Haryadi, dan A Sudrjadjat. 2006. Permasalahan Umum dan Rekomendasi Solusi Budidaya udang vaname (Litpenaeus Vannamei) di Jawa Timur. Dalam A. Sudradjat, E.S. Heruwati dan B. Priono (Editor). Analisis Kebijakan Perikanan Budidaya. Badan Riset Kelautan dan Perikanan, DKP. Jakarta.

The Nation. 2008. Thailand Cuts Shrimp Production. 17 December 2008.

USAID. 2006. A Pro-Poor Analysis of the Shrimp Sector in Bangladesh. Greater Access to Trade Expantsion (GATE) Project for the U.S. Agency for International Development. Arlington, Virginia.
Valderrama, D. and C.R. Engle. 2004. Farm-Level Economic Effects of Viral Diseases on Honduras Shrimp Farms. Journal of Applied Aquaculture, 16(1/2):1-25.

Widigdo, B. and J. Pribadi. 2005. Biosecurity as A Management Tool to Control Viral Diseases and to Improve Production in Shrimp Industry. Paper presented at the World Aquaculture Society (WAS), Bali.

World Bank. 2006. Pakistan Growth and Export Competitiveness. Report No.35499-PK. Poverty Reduction and Economic Management Sector Unit South Asia Region. World Bank, Washington D.C.

Wyban, J. 2007. Thailand's Shrimp Revolution. Aquaculture Asia Pacific Magazine May/ June 2007. 56-58 $p$ 


\section{Lampiran 1. Pertumbuhan Hasil Produksi dan Penggunaan Input Tambak Indonesia, 1989-2008.}

Annex 1. Indonesian Farmed Shrimp Output dan Input Growth, 1989-2008.

\begin{tabular}{|c|c|c|c|c|c|c|}
\hline \multirow{2}{*}{ No. } & \multirow{2}{*}{ Variabel/ variables } & \multicolumn{5}{|c|}{ Periode Pengamatan } \\
\hline & & 1989-2008 & 1989-1993 & 1994-1998 & 1999-2003 & 2004-2008 \\
\hline A. & Output & & & & & \\
\hline \multirow[t]{3}{*}{1.} & $\begin{array}{l}\text { Udang Windu (ribu kg) } \\
\text { /Black tiger (000 tons) }\end{array}$ & 103,607 & 87,452 & 87,983 & 107,352 & 136,398 \\
\hline & $\begin{array}{l}\text { Laju pertumbuhan/thn/ } \\
\text { growth rate per year }\end{array}$ & $4.9 \%$ & $10.0 \%$ & $-2.4 \%$ & $12.6 \%$ & $0.4 \%$ \\
\hline & $\begin{array}{l}\text { Pangsa terhadap penerimaan/ } \\
\text { Black tiger income share }\end{array}$ & $63.1 \%$ & $70.1 \%$ & $64.7 \%$ & $69.0 \%$ & $48.5 \%$ \\
\hline \multirow[t]{3}{*}{2} & $\begin{array}{l}\text { Udang Putih (ribu kg)/ } \\
\text { white shrimp (000 tons) }\end{array}$ & 83,101 & 44,659 & 54,751 & 49,394 & 185,823 \\
\hline & $\begin{array}{l}\text { Laju pertumbuhan/thn/ } \\
\text { growth rate per year }\end{array}$ & $14.1 \%$ & $11.5 \%$ & $-0.5 \%$ & $6.8 \%$ & $38.2 \%$ \\
\hline & $\begin{array}{l}\text { Pangsa terhadap penerimaan/ } \\
\text { White shrimp income share }\end{array}$ & $22.1 \%$ & $17.6 \%$ & $19.9 \%$ & $12.0 \%$ & $38.7 \%$ \\
\hline \multirow[t]{3}{*}{3} & $\begin{array}{l}\text { Bandeng (ribu kg)/ } \\
\text { milky }(000 \mathrm{~kg})\end{array}$ & 190,635 & 146,234 & 153,570 & 218,351 & 249,766 \\
\hline & $\begin{array}{l}\text { Laju pertumbuhan/thn/ } \\
\text { growth rate per year }\end{array}$ & $5.1 \%$ & $8.4 \%$ & $-0.3 \%$ & $8.2 \%$ & $4.8 \%$ \\
\hline & $\begin{array}{l}\text { Pangsa terhadap penerimaan/ } \\
\text { Milky fish income share }\end{array}$ & $14.8 \%$ & $12.3 \%$ & $15.4 \%$ & $19.0 \%$ & $12.8 \%$ \\
\hline B. & Input & & & & & \\
\hline \multirow[t]{3}{*}{1} & $\begin{array}{l}\text { Benur (juta ekor)/ } \\
\text { Fry (million tail) }\end{array}$ & 22,507 & 5,054 & 14,450 & 33,328 & 37,925 \\
\hline & $\begin{array}{l}\text { Laju pertumbuhan/thn/ } \\
\text { growth rate }\end{array}$ & $31.9 \%$ & $53.0 \%$ & $53.3 \%$ & $13.5 \%$ & $12.2 \%$ \\
\hline & $\begin{array}{l}\text { Pangsa terhadap pengeluaran/ } \\
\text { Fry cost share }\end{array}$ & $13.4 \%$ & $13.0 \%$ & $14.6 \%$ & $17.8 \%$ & $9.9 \%$ \\
\hline \multirow[t]{3}{*}{2} & $\begin{array}{l}\text { Pupuk (ribu liter)/ } \\
\text { Fertilizer (000 litre) }\end{array}$ & 11,959 & 13,572 & 9,050 & 8,092 & 17,715 \\
\hline & $\begin{array}{l}\text { Laju pertumbuhan/thn/ } \\
\text { growth rate }\end{array}$ & $8.8 \%$ & $7.1 \%$ & $1.4 \%$ & $4.1 \%$ & $22.1 \%$ \\
\hline & $\begin{array}{l}\text { Pangsa terhadap pengeluaran/ } \\
\text { Fertilizer cost share }\end{array}$ & $0.6 \%$ & $0.7 \%$ & $0.4 \%$ & $0.6 \%$ & $0.6 \%$ \\
\hline \multirow[t]{4}{*}{3} & SDM (ribu HOK) & 55,764 & 33,306 & 42,026 & 59,781 & 88,571 \\
\hline & Laju pertumbuhan/thn & $6.3 \%$ & $5.4 \%$ & $4.0 \%$ & $9.6 \%$ & $6.1 \%$ \\
\hline & $\begin{array}{l}\text { Pangsa terhadap pengeluaran/ } \\
\text { Wages cost share }\end{array}$ & $32.0 \%$ & $31.6 \%$ & $30.1 \%$ & $34.1 \%$ & $30.4 \%$ \\
\hline & $\begin{array}{l}\text { Pakan (ribu kg)/ } \\
\text { Feed }\end{array}$ & 190,279 & 133,189 & 146,234 & 159,625 & 328,849 \\
\hline \multirow{2}{*}{4} & Laju pertumbuhan/thn & $8.5 \%$ & $9.9 \%$ & $-1.9 \%$ & $10.4 \%$ & $16.1 \%$ \\
\hline & $\begin{array}{l}\text { Pangsa terhadap pengeluaran/ } \\
\text { Feed cost share }\end{array}$ & $41.0 \%$ & $42.8 \%$ & $39.5 \%$ & $38.3 \%$ & $42.7 \%$ \\
\hline \multirow[t]{3}{*}{5} & Obat (ribu liter) & 561 & 417 & 334 & 675 & 724 \\
\hline & Laju pertumbuhan/thn & $15.0 \%$ & $-5.5 \%$ & $15.6 \%$ & $9.1 \%$ & $36.8 \%$ \\
\hline & $\begin{array}{l}\text { Pangsa terhadap pengeluaran/ } \\
\text { Medicine cost share }\end{array}$ & $0.3 \%$ & $0.3 \%$ & $0.1 \%$ & $0.4 \%$ & $0.2 \%$ \\
\hline \multirow[t]{3}{*}{6} & Energi (ribu KwH) & 721,421 & 284,448 & 712,901 & 572,825 & $1,350,847$ \\
\hline & Laju pertumbuhan/thn & $28.6 \%$ & $38.6 \%$ & $22.8 \%$ & $1.9 \%$ & $53.0 \%$ \\
\hline & $\begin{array}{l}\text { Pangsa terhadap pengeluaran/ } \\
\text { energy cost share }\end{array}$ & $13.0 \%$ & $11.7 \%$ & $15.5 \%$ & $8.9 \%$ & $16.6 \%$ \\
\hline
\end{tabular}


Lampiran 2. Karakteristik dari Penentu TFP untuk Tipe Usaha Intensif dan Tidak Intensif. Annex 2. Charceteristics of TFP Determinants for Intensive and Non Intensive Culture Systems.

\begin{tabular}{|c|c|c|c|c|}
\hline $\begin{array}{l}\text { Sistem Usaha / } \\
\text { Culture System }\end{array}$ & $\begin{array}{l}\text { Rata-rata/ } \\
\text { Mean }\end{array}$ & $\begin{array}{l}\text { Terendah/ } \\
\text { Minimum }\end{array}$ & $\begin{array}{l}\text { Tertinggi/ } \\
\text { Maximum }\end{array}$ & $\begin{array}{l}\text { Standard } \\
\text { Deviation }\end{array}$ \\
\hline \multicolumn{5}{|l|}{ Intensif/Intensive } \\
\hline $\begin{array}{l}\text { Luas (ha)/ } \\
\text { Farm size (ha) }\end{array}$ & 1.6 & 0.1 & 28.0 & 3.5 \\
\hline $\begin{array}{l}\text { Produksi (kg/ha)/ } \\
\text { Yields (kg/ha) }\end{array}$ & $13,113.4$ & $3,040.0$ & $25,571.4$ & $4,199.9$ \\
\hline $\begin{array}{l}\text { Jumlah benur per Ha (ekor)/ } \\
\text { Fry per ha (tail/ha) }\end{array}$ & $943,957.6$ & $108,000.0$ & $1,700,000.0$ & $334,878.5$ \\
\hline $\begin{array}{l}\text { Jumlah pakan per } \mathrm{Ha}(\mathrm{kg}) / \\
\text { Feed per ha }(\mathrm{kg})\end{array}$ & $21,008.1$ & $1,062.5$ & $40,215.0$ & $6,936.6$ \\
\hline $\begin{array}{l}\text { Harga jual per } \mathrm{kg}(\mathrm{Rp}) / \\
\text { Farm gate price per } \mathrm{kg}(\mathrm{Rp})\end{array}$ & $34,523.5$ & $18,500.0$ & $60,000.0$ & $7,135.9$ \\
\hline $\begin{array}{l}\text { Lama Pendidlkan (tahun)/ Length of } \\
\text { education (years) }\end{array}$ & 16.9 & 6.0 & 17.0 & 1.1 \\
\hline $\begin{array}{l}\text { Tingkat kelangsungan hidup(\%)/ } \\
\text { survival rate (\%) }\end{array}$ & 0.8 & 0.3 & 1.0 & 0.2 \\
\hline $\begin{array}{l}\text { Lama pemeliharaan (hari)/ } \\
\text { length of cultivation (days) }\end{array}$ & 110.4 & 79.0 & 140.0 & 15.2 \\
\hline $\begin{array}{l}\text { Ukuran panen }(\mathrm{ekor} / \mathrm{kg}) / \\
\text { harvest size (tail/kg) }\end{array}$ & 63.0 & 33.0 & 80.0 & 10.9 \\
\hline \multicolumn{5}{|l|}{ Non-Intensif/Non-Intensive } \\
\hline $\begin{array}{l}\text { Luas (ha)/ } \\
\text { Farm size (ha) }\end{array}$ & 7.6 & 0.4 & 50.0 & 9.9 \\
\hline $\begin{array}{l}\text { Produksi }(\mathrm{kg}) / \\
\text { Yield }(\mathrm{kg})\end{array}$ & 92.8 & 12.5 & 500.0 & 89.2 \\
\hline $\begin{array}{l}\text { Jumlah benur per Ha (ekor)/ } \\
\text { Fry per ha (tail) }\end{array}$ & $18,393.5$ & 750.0 & $100,000.0$ & $16,284.9$ \\
\hline $\begin{array}{l}\text { Jumlah pakan per } \mathrm{Ha}(\mathrm{kg}) / \\
\text { Feed per ha }(\mathrm{kg})\end{array}$ & 61.0 & - & $2,000.0$ & 311.3 \\
\hline $\begin{array}{l}\text { Harga jual per } \mathrm{kg}(\mathrm{Rp}) / \\
\text { Farm gate pricess per } \mathrm{kg}(\mathrm{Rp})\end{array}$ & $49,849.0$ & $29,000.0$ & $68,000.0$ & $9,485.6$ \\
\hline $\begin{array}{l}\text { Lama Pendidlkan (tahun)/ } \\
\text { length of education (year) }\end{array}$ & 10.9 & 6.0 & 17.0 & 3.6 \\
\hline $\begin{array}{l}\text { Tingkat kelangsungan hidup(\%)/ } \\
\text { survival rate (\%) }\end{array}$ & 0.3 & 0.0 & 1.0 & 0.2 \\
\hline $\begin{array}{l}\text { Lama pemeliharaan (hari)/ } \\
\text { length of cultivation (days) }\end{array}$ & 95.1 & 75.0 & 130.0 & 11.8 \\
\hline $\begin{array}{l}\text { Ukuran panen (ekor/kg)/ } \\
\text { harvest size (tail/kg) }\end{array}$ & 45.8 & 25.0 & 120.0 & 16.1 \\
\hline
\end{tabular}

Sumber: data diolah/Source: secondary data, processed 
Lampiran 3. Karakteristik dari Penentu TFP antara Tambak di Provinsi Jawa Timur dan di luar Jawa Timur.

Annex 3. Characteristis of TFP Determinants between East Java and Non East Java.

\begin{tabular}{|c|c|c|c|c|}
\hline $\begin{array}{c}\text { Lokasi Karakteristik/ } \\
\text { Location Characteristics }\end{array}$ & $\begin{array}{c}\text { Rata-rata/ } \\
\text { Mean }\end{array}$ & $\begin{array}{l}\text { Terendah/ } \\
\text { Minimum }\end{array}$ & $\begin{array}{l}\text { Tertinggi/ } \\
\text { Maximum }\end{array}$ & $\begin{array}{l}\text { Standard } \\
\text { Deviation }\end{array}$ \\
\hline \multicolumn{5}{|l|}{$\begin{array}{l}\text { Jawa Timur/ } \\
\text { East Java }\end{array}$} \\
\hline Luas (ha)/Farm size (ha) & 7.0 & 0.1 & 50.0 & 9.5 \\
\hline Produksi (kg)/Yields(kg/ha) & 5,600 & 14.3 & 25,000 & $7,112.3$ \\
\hline $\begin{array}{l}\text { Jumlah benur per Ha (ekor)/ } \\
\text { Fry per ha (tail/ha) }\end{array}$ & 370,335 & 750.0 & $1,700,000.0$ & $472,928.5$ \\
\hline $\begin{array}{l}\text { Jumlah pakan }(\mathrm{kg} / \mathrm{ha}) / \\
\text { Feed }(\mathrm{kg} / \mathrm{ha})\end{array}$ & 8,551 & - & $37,250.0$ & $11,053.7$ \\
\hline $\begin{array}{l}\text { Harga jual }(\mathrm{Rp} / \mathrm{kg}) / \text { Farm gate } \\
\text { prices }(R p / \mathrm{kg})\end{array}$ & $47,247.8$ & $29,000.0$ & $68,000.0$ & $9,397.1$ \\
\hline $\begin{array}{l}\text { Lama Pendidlkan (tahun)/length } \\
\text { of education (year) }\end{array}$ & 13.5 & 6.0 & 17.0 & 4.0 \\
\hline $\begin{array}{l}\text { Tingkat kelangsungan hidup (\%)/ } \\
\text { survival rate (\%) }\end{array}$ & 0.5 & 0.1 & 1.0 & 0.3 \\
\hline $\begin{array}{l}\text { Lama pemeliharaan (hari)/ } \\
\text { length of cultivation (days) }\end{array}$ & 98.3 & 75.0 & 140.0 & 17.3 \\
\hline $\begin{array}{l}\text { Ukuran panen (ekor } / \mathrm{kg}) / \\
\text { harvest size (tail/kg) }\end{array}$ & 51.0 & 30.0 & 120.0 & 15.6 \\
\hline \multicolumn{5}{|l|}{$\begin{array}{l}\text { Di luar Jawa Timur / } \\
\text { Outside of East Java }\end{array}$} \\
\hline Luas (ha)/Farm size (ha) & 1.2 & 0.2 & 17.0 & 2.2 \\
\hline Produksi (kg)/Yields (kg) & $10,582.3$ & 12.5 & $25,571.4$ & $6,335.3$ \\
\hline $\begin{array}{l}\text { Jumlah benur per Ha (ekor)/Fry } \\
\text { per ha (tail) }\end{array}$ & $796,926.2$ & $10,000.0$ & $1,650,000.0$ & $479,748.7$ \\
\hline $\begin{array}{l}\text { Jumlah pakan per } \mathrm{Ha}(\mathrm{kg}) / \\
\text { Feed per ha }(\mathrm{kg})\end{array}$ & $18,055.4$ & 0 & $40,215.0$ & $9,959.2$ \\
\hline $\begin{array}{l}\text { Harga jual per } \mathrm{kg}(\mathrm{Rp}) / \text { Farm } \\
\text { gate process per } \mathrm{kg}(\mathrm{Rp})\end{array}$ & $34,275.6$ & $18,500.0$ & $62,000.0$ & $8,367.8$ \\
\hline $\begin{array}{l}\text { Lama Pendidlkan (tahun)/ } \\
\text { length of education (year) }\end{array}$ & 15.7 & 6 & 17.0 & 3.1 \\
\hline $\begin{array}{l}\text { Tingkat kelangsungan hidup (\%)/ } \\
\text { survival rate (\%) }\end{array}$ & $73 \%$ & $3 \%$ & $99 \%$ & $29 \%$ \\
\hline $\begin{array}{l}\text { Lama pemeliharaan (hari)/ } \\
\text { length of cultivation (days) }\end{array}$ & 110.1 & 85.0 & 130.0 & 12.2 \\
\hline $\begin{array}{l}\text { Ukuran panen (ekor } / \mathrm{kg}) / \\
\text { harvest size (tail/kg) }\end{array}$ & 61.4 & 25.0 & 86.0 & 13.7 \\
\hline
\end{tabular}

